\title{
THE IMPACT OF CONTINUOUS AND ONGOING PROFESSIONAL DEVELOPMENT ON THE NURSING PROCESS OF TAKING CARE OF NEUROLOGICAL PATIENTS
}

\author{
Lenka Kopačević ${ }^{1}$, Vesna Božan Mihelčić ${ }^{2}$, Sonja Antić ${ }^{1}$ and Vida Demarin ${ }^{1}$
}

${ }^{1}$ Clinical Department of Neurology, Referral Center for Neurovascular Disorders of the Ministry of Health of the Republic of Croatia, Referral Center for Headache of the Ministry of Health of the Republic of Croatia, Sestre milosrdnice University Hospital Center; ${ }^{2}$ Zagreb-Centar Primary Health Center, Zagreb, Croatia

\begin{abstract}
SUMMARY - Nurses distinguish continuous professional development intended for career improvement and personal development from continuous professional development intended for improvement of skills and knowledge. Too many requests are put in front of an individual unacceptably stretching it onto the life outside work. Students have various expectations from their education. Factors that motivate nurses to study are to improve knowledge, patient care and professional relations. Factors connected to personal development include boost of confidence and embracing of other values. Motivation for additional education is also connected to the change of work, practice improvement, self-confidence improvement, nursing career plans, and necessary intellectual stimulation. The reasons for which nurses decide to undertake further education are also desire for maintenance of clinical competence, but also enjoyment in studying itself. An employer who expects from nurses to opt for such a type of education or stimulate it is another common reason.
\end{abstract}

Key words: Continuous professional development; Nursing practice; Education; Motivation

\section{Introduction}

Studies conducted over the past decade in countries implementing planned continuous professional development have established that nurses differentiate between continuous professional development intended for career advancement as well as personal development and continuous professional development model for improving knowledge and skills. One of the conclusions is that too many demands have been placed upon the individual, thus unacceptably extending professional life to the life outside of work. These findings also confirm that students have different ex-

Correspondence to: Lenka Kopačević, RN, Clinical Department of Neurology, Sestre milosrdnice University Hospital Center, Vinogradska c. 29, HR-10000 Zagreb, Croatia

E-mail: 1kopacevic@gmail.com

Received June 1, 2012, accepted January 17, 2013 pectations from education. The research involved both personal and professional factors. The factors that motivate nurses to study are to upgrade their knowledge, improve patient care, and enhance professional relationships. Factors associated with personal development include increasing trust and opening of other possibilities. Motivation for further education is also associated with job change, improving practices, improving self-esteem, plan for nursing careers, and the necessary intellectual stimulation. The reasons why nurses choose further education is also desire to maintain clinical competence and satisfaction of studying itself. The employers who expect from nurses to opt for such a type of education or stimulate it are another common reason.

Raising self-esteem is assessed as a very important reason. It is assumed that nurses may have lost confidence in their traditionally acquired skills. In one 
study, ninety-nine percent of respondents estimated that the reason offered for advancement to a higher position was very important. Yet, other studies confirm that nurses assess the increase of business opportunities that are available within the nursing as a major opportunity for improvement. In a vast majority of studies, one of the factors that motivate nurses to study was improvement of patient care. Some participants felt they would benefit from continuous education in terms of their own self-esteem, believing that they had missed something in their education, while others wanted to continue studying in order to prevent its stagnation. Furthermore, some of these participants identified gaps in their prior education. From the professional standpoint, individuals feel under pressure from their work environment to embark on further education. There is an assumption that those who participate in further education do so in order to raise their income. Employees who continue their education on average have higher incomes than those who do not attend school.

\section{Methods}

It was necessary to consolidate preliminary data for analysis and prepare them for statistical analysis. The method of data generalization and their processing in the Office Access was used for the purpose of this study.

\section{Results}

In the year 2007, a survey was conducted at all sites and activities of nurses in neurology in Croatia on a sample of 622 respondents. Data were collected using an anonymous questionnaire designed for the purpose of this study. Since 2007 , only $12 \%$ of nurses have been involved in the education process in the field of nursing.

Analysis of data showed that a small number of respondents opted for education after high school, only $8 \%$ of the total sample, even though $60 \%$ expressed desire for further education; $65 \%$ of respondents considered education necessary for their future work; $31 \%$ of respondents thought that education was not one of the conditions for their future work in the profession; and $4 \%$ of the respondents had no defined answer to the question. The analysis did not determine the reasons and the biggest obstacle to continued training of neurological nurses who wished but were not able to enroll in the required studies. It may be assumed that the reasons were the lack of time, working shifts, the lack of will and motivation, undefined professional status, finances, employers' support in terms of finance, and ensuring free time education.

The same survey was conducted in the late 2009. With regard to the adjustment of Croatian legislation during negotiations to join the European Union, the survey was expanded to include additional questions. The survey included 132 head nurses at all sites and nursing activities as well as rehabilitation points in neurology and neurological departments at the national level. Now, $87 \%$ of respondents considered continuous professional development through permanent professional improvement necessary in everyday work. Although the majority (45\%) were not inclined to enroll in graduate nursing clinical studies, $31 \%$ of them claimed they would do it all again; 94\% of respondents believed that status quo should have been recognized as the place of nurses, and only $6 \%$ did not. Most respondents (43\%) did not know whether the study would live up to their expectations, but $94 \%$ agreed that residency for neurological nurses should not be within the internist residency. Specifically, a tendency is to take place within the same residency of internal activity. The fact is that until now residency program for nurses with secondary school education in the activities of neurology has not yet been defined. Not even legal provisions bring any instructions on how to conduct residency for neurological nurses. At the same time, the second year of graduate studies in clinical nursing at neurology department provides

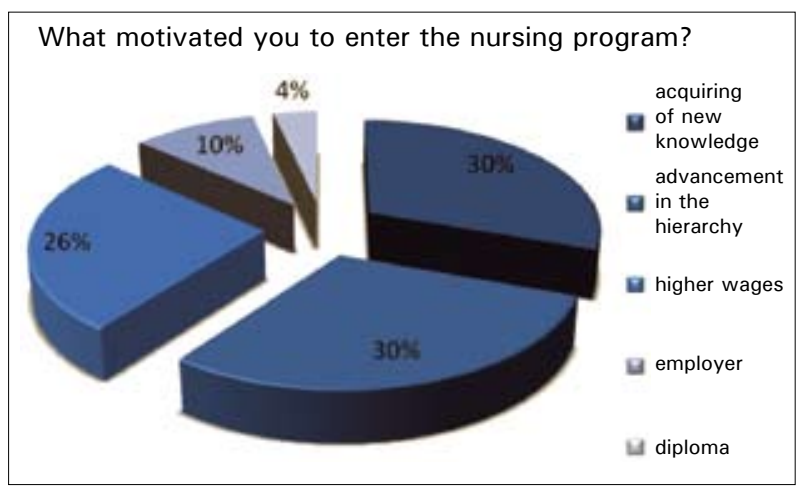

Fig. 1. Motivation for learning. 


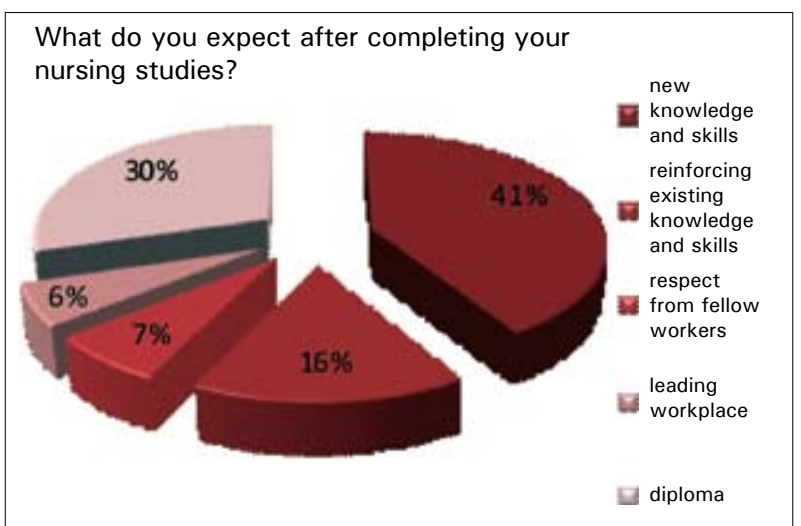

Fig. 2. General expectations from nursing studies.

courses in all areas of health care of neurological patients, including neurorehabilitation, neuropediatrics, research in the field of neurology, ecology, diagnosis, etc.

In order to get some answers why nurses continue their education, in 2010 the research was conducted in a sample of 106 nursing undergraduate students at the University of Applied Health Studies in Zagreb. Now, $30 \%$ of respondents stated acquisition of new knowledge and also advancement on the hierarchical scale as the motive for enrolment in the nursing study. Other motives were higher payment, employer, and diploma on the last place (Fig. 1).

The other motives were higher wages, the employer and awards on the last place. Upon completion of the nursing study, $39 \%$ of respondents expected to acquire new knowledge and skills, even 30\% higher payment, $11 \%$ reinforcement of the already acquired knowledge and skills, but also a leading working place, and only 9\% respect from coworkers (Fig. 2).

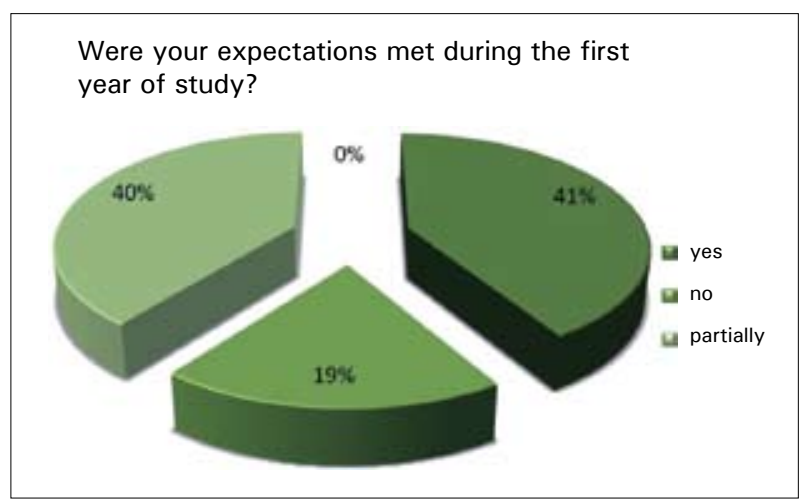

Fig. 3. Expectations from the first year of study.

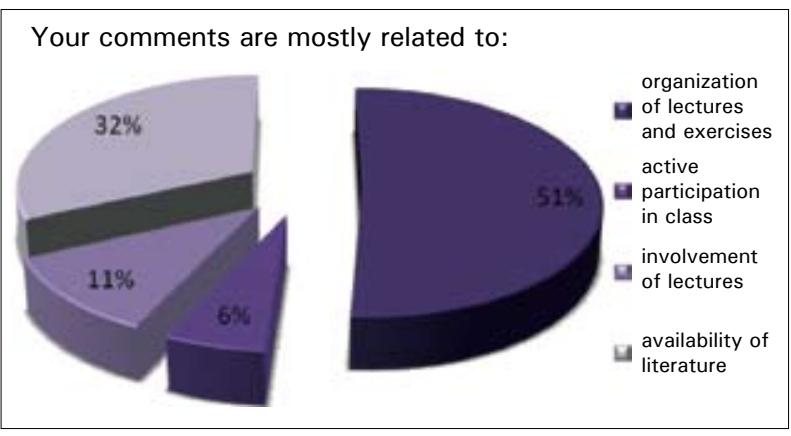

Fig. 4. Comments on organization of the study.

The expectations were mostly met in $41 \%$ of first year students and only partially in $40 \%$ of the respondents (Fig. 3).

Students mostly commented on the organization of lectures and training (51\%), followed by literature availability (32\%), and involvement of teachers (11\%), at least their active participation in class work (Fig. 4).

The majority of respondents (46\%) had problems with coordination of work schedule, $30 \%$ partially, and $24 \%$ of students had no such problems (Fig. 5).

Upon completion of the study, $43 \%$ of respondents believed that new knowledge and skills could be applied in practicing general health care, $31 \%$ believed it to be applicable in special health care, $25 \%$ of respondents would apply the same knowledge and skills in the education of patients, and only $1 \%$ in nursing management (Fig. 6).

\section{Discussion}

Results of the studies conducted in the countries that provide continuous professional development can

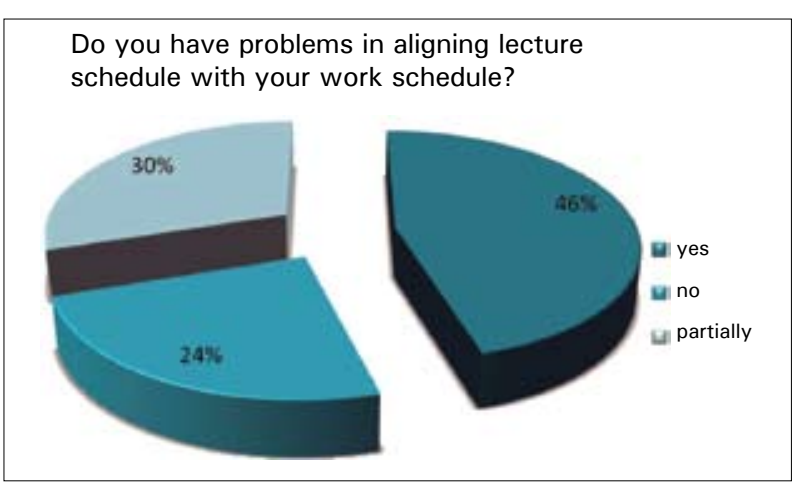

Fig. 5. Problems with aligning lectures and work schedule. 


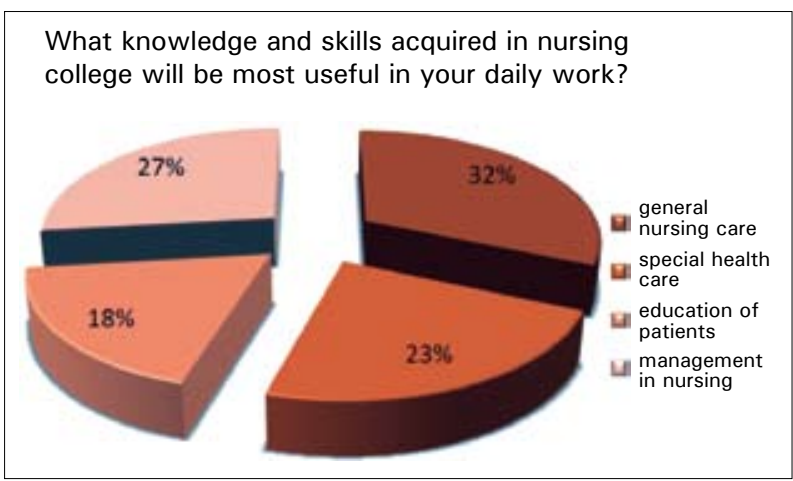

Fig. 6. Application accomplishments in daily work after study.

be interpreted in several ways. Although the most important reason for continuing education has been advancement on the job, according to the responses, the highest percentage of subjects continue their education in order to improve their clinical assessment and expand their clinical role. A smaller percentage of subjects refer to the claim to increase business opportunities within the nursing/health care. Improvement of practical skills and plans for career in nursing are equally important. This may mean that there is a broad interest in moving horizontally in various aspects of nursing rather than in continuing professional vertical advancement. In wider debate, the possibility of further education that will result in professional and personal improvement should certainly be involved in decisions on their further education.

The results of the study can also be interpreted in a way that even the nurses that are not very dedicated to the type of work or are currently not satisfied with their employers should take part in the continuous professional development either to escape or as part of a strategy to find a future job that they find more appropriate.

Studies conducted at all sites in Croatia where neurology medical nurses work have confirmed strong interest of the nurses in further education after completing secondary education, but also a small percentage of their enrolment in undergraduate professional studies. Although the majority of respondents thought their further education to be important in their daily work, a large number of respondents did not know whether the stated course would meet their expectations. They believe that we should recognize the status quo according to their current working places. Most subjects were not inclined to enroll in graduate studies of clinical nursing, but almost all of them agreed that it should be implemented within the same residency internist activities. The desire to acquire new knowledge and advancement possibilities are the main motivators for enrolment. What they expect from professional study courses is acquisition of new knowledge and skills, and higher salaries after graduation. The expectations are met in a greater percentage of students after the first year of study. The main objections to the study refer to the organization of lectures and exercises, and the least of them object to active participation. A large number of students had problems in combining the study schedule with their working schedule. The result that the majority of respondents will use the adopted knowledge in general care, while only a small part will use it for patient education calls for further discussion.

The fact is that there are a large number of nurses who after graduation have not changed their position very often or for many years. Until the passing of the Nursing Act (OG 121/03), they did not receive any kind of training even at their worksite. The quality of their professional judgment, usually important for the quality of their work, is questionable in such cases. Inevitably, it seems that their knowledge cannot follow the job requirements, thus making them reluctant to any change. Patients, on the other hand, experience nurses in a positive way, but expect from them nothing important to their health, while a doctor in their opinion deserves respect. Sometimes this results in insecure and scared patient, since doctor often does not have time to talk to him, communication between doctors and nurses does not take place at the level of equal members of the team, the doctor does not have confidence in the nurses and underestimates them, the nurse then takes defensive stand feeling insecure with low self-esteem, finally resulting in poor and unprofessional communication with the patient.

There is much discussion on what constitutes support for continuing professional development and what can be a key factor that leads to an individual's decision to take part in it. Education is expensive and time-consuming in terms of financial, personal and professional commitment, and demands careful consideration of the potential participants as well as the entity that bears the cost of schooling. The cost of re- 
placing the staff during their absence due to education affects the manpower and skill combination. Two additional barriers have been identified as a challenge. One is convincing the head nurses that the staff progress is of vital importance for the nursing service, and the other is explaining the importance of a systematic approach to identifying training needs and training itself. The necessity of nursing, the number of nurses and the cost of services rendered is an omnipresent discussion. This discussion also extends to the fact that expecting the results without financial investment is not realistic, especially if striving for excellence. The more nurses are satisfied with their careers and the longer their work period together with the knowledge and skills they acquire throughout their education, the higher is their expertise and the acquired experiences. Therefore, such an investment will not only help retain nurses in there field of work, but will also contribute to the quality of the workforce.

\section{Relevance for Clinical Practice}

Good organization of health care implementation in hospitals, which is always based on well-educated and competent nurses, can significantly affect the overall success of treatment, which in turn has both expert and financial effects. Since nurses engaged in hospital care carry out more than $80 \%$ of all the procedures in 24 hours, their impact on total care is proportional to their share in health care. It should be noted that nurses' expertise is most important, but so are other elements such as sufficient number of nurses, good distribution based on changing needs, good equipment and accessories for health care implementation and space conditions.

\section{Research Policy}

Continuous, systematic standardized collection, analysis and interpretation of data related to plans for permanent training and comparison with health statistics can be useful in the educational system when creating programs that will result in competent and competitive workers. Determination of priorities, ongoing program evaluation and research encouragement can be of utmost importance to support individuals and groups in career management and professional development.

\section{Management and/or Education}

In order to provide good health care services to individuals or groups, policy makers and vocational guiders should take into account the transparency and easy access when planning the education. They should focus on the key issues related to the current needs of the health system, take into account the flexibility and innovation in presentation skills, the ability of research and collect data in various fields of nursing activities, access to verified and integrated information from areas of interest to nursing activities, and creation of a structured database.

\section{Conclusion}

A permanently educated nurse will be able to assess the needs of patients on time and consequently organize proper provision of health care by using all human and technical resources.

\section{References}

1. GOULD D, DREY N, BERRIDGE EJ. Nurses' experiences of continuing professional development. Nurse Educ Today 2007;27:602-9.

2. DAVEY B, MURRELLS T. To get better job or to do the job better: motivations of registered general nurses to participate in post-registration degrees. Learn Health Soc Care 2002;1:139-49.

3. SMITH J, TOPPING A. Unpacking the 'value added' impact of continuing professional education: a multi-method case study approach. Nurse Educ Today 2001;21:341-9.

4. CALPIN-DAVIES PJ. Demand for post-qualifying professional education in the health care sector in England. J Adv Nurs 1996;24:800-9.

5. YEUN F. Case study of learning milieus: the modifying effect of the workplace. J Adv Nurs 1991;16:1290-5. 
Sažetak

\section{UTJECAJ TRAJNE STRUČNE IZOBRAZBE I USAVRŠAVANJA NA PROCES SESTRINSKE SKRBI ZA NEUROLOŠKE BOLESNIKE}

\section{Kopačević, V. Božan Mihelčić, S. Antič i $V$. Demarin}

Medicinske sestre razlikuju kontinuirani profesionalni razvoj namijenjen unapređenju karijere i osobnog razvoja od kontinuiranog profesionalnog razvoja namijenjenog unapređenju znanja i vještina. Previše zahtjeva stavlja se pred pojedinca koji se neprihvatljivo protežu na život izvan radne sredine. Studenti imaju različita očekivanja od obrazovanja. Čimbenici koji motiviraju medicinske sestre za studiranje uključuju unapređenje znanja, skrbi o bolesnicima i profesionalnih veza. Čimbenici povezani s osobnim razvojem uključuju povećanje povjerenja i otvaranje drugih mogućnosti. Motivacija za dodatno obrazovanje povezana je i s promjenom poslova, unapređivanjem prakse, unapređivanjem samopouzdanja, planova za sestrinsku karijeru i potrebnu intelektualnu stimulaciju. Razlozi zbog kojih se medicinske sestre odlučuju na daljnje obrazovanje su i želja za održavanjem kliničke stručnosti, ali i uživanje u samom studiranju. Čest razlog je i poslodavac koji očekuje da se medicinske sestre odluče na takvu vrstu usavršavanja ili ju i sami potiču.

Ključne riječi: Trajno stručno usavršavanje; Sestrinska praksa; Izobrazba; Motivacija 